\title{
TOURISM TRANSITIONS, CHANGES, AND THE CREATION OF NEW SPACES AND PLACES IN CENTRAL-EASTERN EUROPE
}

\author{
Marek Więckowski ${ }^{1}$ (D) Jarkko Saarinen ${ }^{2,3}$ \\ ${ }^{1}$ Institute of Geography and Spatial Organization \\ Polish Academy of Sciences \\ Twarda 51/55, 00-818 Warsaw: Poland \\ e-mail: marekw@twarda.pan.pl \\ ${ }^{2}$ Geography Research Unit \\ University of Oulu \\ Pentti Kaiteran katu 1, Room KE368-3, FI-90014 University of Oulu: Finland \\ e-mail: jarkko.saarinen@oulu.fi \\ ${ }^{3}$ School of Tourism and Hospitality \\ University of Johannesburg \\ South Africa
}

\begin{abstract}
This paper outlines the general context of tourism, and the changes it underwent, in the Central and Eastern Europe (CEE) countries post-1990. The role of European Union enlargement is also discussed, allowing for an overall highlighting of the outcomes for tourism of the CEE countries' political, administrative and institutional transformations. In essence, the development of transport systems and infrastructure have combined with the changing socio-economic conditions people experience to impact economically, socially and culturally - expanding the opportunities where tourism is concerned, as well as competition between countries and regions when it comes to attracting both tourists as such and investors. More specifically, the rapid privatisation of state-owned assets ensured a major impact in changing and developing tourism in the CEE, with the communist/post-communist structural changes in general proving a crucial catalyst underpinning most of the changes noted. This paper further serves the function of concluding contributions making up this special issue, and thus seeks to outline new future directions by which tourism in the CEE countries can be researched from the perspective of human geography.
\end{abstract}

\section{Key words}

Tourism - transition - post-communism - Central and Eastern European countries (CEE) • development - European Union 


\section{Introduction}

Constant change would seem to be feature typifying tourist destinations, not least as the creation and development of spaces for tourism are seen to reflect wider political, economic and social processes often driven non-locally, if manifesting themselves very locally indeed. From the point of view of geography, tourist destinations can be seen as spatial units generated historically, which are developed, marketed and experienced through the intermediation of various economic, political, social and cultural forces, as well as histories and practices, all assuming specific forms in specific places (Saarinen 2004). While change may always have been an aspect typical for tourism, today in all probability the spaces in which it takes place, and the destination/ recipient communities are being influenced and transformed much more profoundly and rapidly and on a more non-local basis - even as regards their sense of place and identity (Saarinen 2014). In some places, specific turning points and radical contextual changes may have proved extremely influential, with profound elements causing tourism development to transit in completely new directions (Müller 201; Mayer et al. 2019). The fall of the Berlin Wall and the relatively rapid dissolution of the Soviet-dominated COMECON/Warsaw Pact system from the beginning of the 1990s for example ensured radical change and new paths of development in Europe's tourism space in general, and of course in the Central and Eastern European (CEE) countries in particular.

Overall, the time since the 1990s, following on in the wake of crucial and massive geopolitical and socio-economic transition, has seen the tourism industry in the CEE countries assuming ever-greater socio-economic, cultural and political importance. Indeed, there are many places in which tourism has played a crucial role in improving peoples' wellbeing, raising their quality of life and ensuring both infrastructural development and a willingness to open borders. This increasing importance of tourism has also served as the topic for one of academia's most rapidly developing, interdisciplinary fields of study. This fact is made clear enough by the growing numbers of books, journal papers and academic conferences devoted to the matter, and also by the coming into being of this Special Issue of Geographia Polonica. Here, the specific aim is to focus on ongoing change and transformation of tourism spaces and places in the CEE countries, along with the impact on these of this region's particular socio-political and economic transitions. This Special Issue is in a position to illustrate just how diverse have been the socio-spatial changes, transitions and formations influencing, guiding or controlling the development of tourism in the CEE countries, on different temporal and spatial scales and in different settings. Before going on to introduce each of the research papers that this Special Issue contains, we shall seek to outline briefly the general context and changes present from the beginning 1990s onward, including the role played by the European Union.

\section{General changes in tourism in the post-communist CEE countries}

After more than four decades during which Poland and other CEE countries developed under the political and economic conditions of the communist era, 1989 ushered in a period of ever-greater transformation in the way the economy in general and tourism in particular developed. Before, both the supply and demand sides of tourism in the CEE countries had largely been in the hands of central government and its various institutions. A further feature of that period related to the closed nature of national and sub-national borders - a decisive factor ensuring clear-cut barriers to movements of both goods and people (the latter including tourists). The development of international tourism in such circumstances was a major challenge, and was highly dependent on geopolitics. The bounded spaces present also had a major influence on the development of tourist infrastructure, 
with special closed zones, military areas and border zones further challenging the development of tourist routes and infrastructure. At a basic level, the location of businesses operations in, or even close to, the zones referred to was very much "discouraged".

All this changed rapidly as the CEE countries became transition economies moving away from the past, and seeing new activity in tourism activities, and indeed the very presence of tourists, as characteristic for ongoing changes in both societies and the production and consumption systems associated with them (Williams \& Baláž 2002b; Hall 2003). In the Western European context, the changes in question have been related to cultural shifts in consumption and production, described in terms of movement from Fordist to post-Fordist production, and related new methods of consumption. Post-Fordist consumption in tourism is often labelled new tourism (deemed to involve "new tourists"), with the consumption and production that entails considered to involve increasing flexibility, individuality, hybridity and activity in general (Poon 1993). However, in the CEE countries, the structural change to post-communist was the most crucial catalyst of all (see Riley 2000), and sometimes understood and interpreted in terms of the set of institutional changes accomplished by national governments during the 1990s (Sykora \& Bouzanovski 2012). Indeed, such structural change has been visibly present as tourism has developed over the last two decades, with tangible outcomes of political, administrative and institutional transformation including a vast and growing number of private firms and entrepreneurs. Some specific institutional transformations, like the privatisation of state-owned assets (e.g. hotels, spa-resorts) have had further impacts in changing and developing tourism in the CEE countries. The development of transport systems and general wellbeing have both led to new economic, social and cultural transformations, with expanding tourist infrastructures, and countries and regions competing to attracting both tourists and investors in tourism.
In addition, new developments in transport infrastructure, increasing traffic, improved air transport and the emergence of low-cost companies have all modified the paths along which tourism in the region develops (see Tóth \& David 2010; Bănică \& Camară, 2011, Michniak et al. 2015; Nilson 2018). Indeed, in the CEE countries the matter of improved accessibility has played a significant role in the development of tourism, though the directions and volumes of tourist flows have been shaped by a range of additional factors, including attractiveness of destination and price. The latter factor is naturally regulated by exchange rates (Więckowski 2010). In turn, internal tourism saw people concerned "to make up for lost time", in particular in the context of a rapid growth in income for many (Banaszkiewicz et al. 2017).

Over the last few decades, the primary impacts exerted on the development of tourism in the CEE countries have revolved around increased mobility, the opening of borders, communication accessibility and attractiveness. More generally societies have been transformed, and integration, globalisation and modernisation have all taken place (Więckowski 2010), with these processes highly visible in the new post-communist tourist space created by the so-called bazaarcapitalism (Stryjakiewicz 1998).

Where research into tourism is concerned, there are many studies on post-1989 spatial transformations, but little attempt at theorising in relation to the phenomena. Riley (2000), for example, underlines concepts relating to top-down and bottom-up influences in the Polish mountains, under communism and then with the market economy. For their part, Saarinen and Kask (2008) showed path-dependency and path-creation as tourism developed in the Estonian town of Pärnu. Finally, Banaszkiewicz et al. (2017) sought to conceptualise the development of tourism in the CEE countries from social and anthropogenic perspectives. 


\section{Entry into the EU and Schengen Zone}

The past three decades have witnessed a transformation from a centrally-planned to a free-market economy, with all the major implications for both the development and the spatial structure of tourism within the CEE countries. This overall change has restructured spaces in which tourist activity takes place; and will continue to do so.

But rather more recently, these processes of change have been further guided by the European Union and its various funding sources targeting regional and local development in rural, urban and cross-border contexts. It was in 2004 that most CEE countries became members of the EU, though certain funding had been received even in the preaccession period. With accession, boundaries took on two main types of status. In Poland, borders with Germany, Czechia (as it became known), Slovakia and Lithuania joined almost the entire maritime boundary in becoming internal frontiers of the European Union. For areas adjacent to these borders, the development of tourism became easier (less under the impact of barriers), and will continue to be so. National Parks are all that now obstruct free travel in internal borderlands in any major way.

Poland's accession to the EU's Schengen Agreement further determined the potential spatial effects of associated changes in the scale of movement across borders in the European Union's interior. A presence within the Schengen Zone means the closure of all border checkpoints and the possibility of borders being crossed at any place along their length. Many old check-points can still be seen on borders, and most go entirely unused today. Some have actually changed into tourist centres offering information, or into retail outlets selling regional products, and/or restaurants. These changes are especially prevalent close to National Parks.

The ongoing intensification of movement may require further development of trans- boundary transport infrastructure (also for pedestrians and cyclists). The cessation of passport control specifically effects the labour market, as happened with the removal of customs clearance in 2004 and 2007. This has the potential to lead to growth in economic activity in the areas immediately adjacent to a border (as a result of the disappearance of restrictions, including even psychological barriers).

Poland's boundaries with Belarus, Ukraine and the Kaliningrad District of the Russian Federation in turn became external frontiers of the European Union. This denoted these areas receiving strengthened protection, with crossing of these borders actually made more difficult. In 2007, these same boundaries became limits of the Schengen Zone, which Poland entered on December 21st that year, along with other eight of the other countries that had joined the EU in 2004. Poland's borders with Germany, the Czech Republic, Slovakia and Lithuania in that way became open internal frontiers of the European Union, as well as the Schengen Zone.

Thus, for several years now, all borders between Poland and fellow Member States of the European Union have been zones of contact, while external borders have come to be closed (though mostly not as tightly as pre-1989). The external frontiers of the European Union do operate as barriers to free travel and the development of tourism, ensuring that the borders involved will probably remain marginal as tourist destinations, if with some exceptions. Certainly, the creation of cross-border tourist regions near the Schengen Zone's external frontiers will prove difficult. Even today, there are many tourist routes leading up to - but ending at - the border, thereby very much limiting the possibilities for immediately adjacent territory of a neighbouring country to be encountered (see Timothy, Saarinen and Viken 2016).

EU enlargement processes have otherwise been associated with openness of borders (especially thanks to Schengen). Processes of political change have caused 
"re-internalisation" of tourism (Williams \& Baláž 2002a), but also - especially in border regions - a so-called cross-borderisation of tourism (Więckowski 2010). This reflects - and also further enhances - both cross-border traffic and cross-border cooperation (Timothy \& Saarinen 2013; Kolosov \& Więckowski 2018; Mayer et al. 2019). Such developments in tourism are of course supported strongly by various European Structural Funds (Timothy \& Saarinen 2013; Studzieniecki \& Meyer 2017; Dołzbłasz 2018). However, applications for EU grants had to meet certain criteria corresponding with trends in tourism in Europe and worldwide. In this way, tasks more fully compatible with sustainable development might be pursued, and best practices and solutions implemented (e.g. Greenways Trails), with consequences being promotion of natural and cultural heritage (Banaszkiewicz et al. 2017).

At the same time, new regulations and control mechanisms were denoted by enlargement within the EU and Schengen Zone. Certain destinations and forms of tourism may have declined as a result, while certain new forms, activities, places and regions have evolved. New tourism infrastructure, attractions and products have certainly been created, and cultural and natural heritage resources are gaining ever-increasing use in tourism serving local and regional development. Sometimes this utilisation has proceeded at the expense of the ecological or socio-cultural environment, with this urgently calling for the achievement of sustainability in the further future. In general, a need has arisen for discussion and critical evaluation of governance, policy, planning, marketing, human mobilities and socio-economic dimensions as all linking up with the growing tourism industry in the CEE countries.

\section{Increasing tourist mobility}

At the beginning of the 1990's, differences in the mobility regimes of the capitalist and communist systems were still evident (Erikson \& Goldthorpe 1992). Generally, there was more long-distance upward and downward mobility, and more inflows into and outflows from the self-employed classes under communism. Types of international mobility were presented by Derek Hall (2000) and divided into four main groups, as: international tourism, small-scale cross-border trading and shopping, labour migration and refugee flight. Mobility of citizens in the CEE countries in terms of international departures proved to be a combination of tourist trips, labour migration and trade (Więckowski 2008). Thanks to increased and changed mobility, people can determine their own social status. Generally, the proportion of holiday trips (of 4 nights or more) within a country, i.e. domestic trips - as compared with those outside the country (outbound) was more than $80 \%$, and was among the highest percentages to be noted in the EU. This is mainly because international mobility is relatively limited by high cost. In addition, citizens of the CEE countries are not very widely familiar with foreign languages. Thus Poles often spend their holidays visiting friends and family in their own country. Regarding the purpose of travel, leisure activities count as the main reason, actually accounting for more than 50-60\% of international trips.

In the last few years, destinations in Central and Eastern Europe also posted solid growth, with a few exceptions. A rapid increase in arrivals was recorded following the enlargement of the European Union, and later on the occasion of cultural or sporting events on an international scale (e.g. Euro 2012 in Poland and Ukraine, and the 2018 FIFA World cup in Russia). The Russian Federation hosted the World Cup and recorded a double-digit increase in receipts due to international tourism. This would be prolonged by a new e-visa regime for entry into Kaliningrad District and the Saint-Petersburg region, as established by the Russian government in July 2019. In addition, visa facilitation led to an increase in numbers of Chinese tourists at some destinations. New regulations and special permissions in the context of non-visa movement introduced by the 
Belarusian government has in turn been resulting in increased interest in foreign tourists from Poland, Lithuania and other EU Member States.

The growing importance of marketing, tourist information and planning has also been observed in the CEE countries. Many new trends have appeared - sometimes even at the same time as in Western European countries. New ideas arise seeking to achieve innovation, and this attests to increasing maturity of the emerging tourist regions in the CEE countries. Safety, a high quality of service and relatively lower prices all help to make the region a magnet for international tourists. Furthermore, many destinations are already of global or continental significance, having become very well-known, and already attracting millions of tourists. Examples here might include capital cities (like Prague and Budapest), other large urban centres (e.g. Kraków and Gdańsk), mountainous areas of picturesque landscape (like the Tatra or Karkonosze Mts.), many UNESCO heritage sites, sea costs and lake districts.

\section{Our Special Issue}

This Special Issues offers six research papers, including a first in which Nikola Naumov and Adi Weidenfeld analyse the way in which the heritage of the communist era in the CEE countries has at times achieved iconic status. Their conceptual paper focuses on the roles of such icons in the post-communist tourist landscape. While it is known that many of these have indeed been removed, others have remained in place and become flagship attractions. The paper introduces a framework for studying relevant socio-spatial processes of transformation, suggesting that iconisation, de-iconisation and re-iconisation are deeply interrelated to other wider strategies and approaches emerging in the CEE countries. Finally, the paper identifies future research needs.

Lucia Petrikovičová, Alfred Krogmann Dana Fialová and Andrej Svorad discuss the impacts of intensive tourism-related urbanisation on the mountain village of Vel'ká Lomnica in Slovakia. Vel'ká Lomnica is a locality in which golf-course construction has fuelled large-scale tourism development projects. The authors map and assess landscape structures and changes whose analysis reveals a major increase in the area assigned to tourism. In addition, they note that intensifying tourism operates mainly in enclaves, which is to say that space dedicated to. tourism has begun to diverge from areas inhabited by the local population.

For her part, Svetlana Stepanova describes the transformation of the Northern Ladoga region in the Russian-Finnish border area - from closed borderland into a prospective tourist destination. She points to key historical, cultural, ecological and economic aspects of the area and to changes therein, before drawing conclusions as regards certain elements that might further stimulate tourism in the region.

Tomasz Napierała analyses evolutionary change in respect of intra-urban development of hotel locations, taking Budapest as his example. He discusses the role of tourism development in the urban environment, and seeks a theoretical approach to the topic by reference to the polycentric development perspective. Empirically, Napierała compares the spatial distribution of hotels and their clustering in Budapest in the period since 1982.

Grigore Vasile Herman, Jan A. Wendt, Răzvan Dumbravă and Maria Gozner study the roles and operations of the centres established in Romania to promote tourism, and the ways in which their marketing works in practice - by reference to a survey-based approach. They conclude that the expansion of tourism at regional and global levels requires major effort if tourist destination management is to be optimised.

Finally, Mariola Tracz and Małgorzata Bajgier-Kowalska profile the tourists visiting the three selected cultural-heritage cities of Budapest, Prague and Warsaw. Their results indicate that most tourists visiting these cities are from Western Europe, and 
are motivated by what cultural tourism has to offer, as well as by the entertainment-related opportunities.

\section{Some future directions}

The current intensification of tourism is one of the most visible social and economic changes affecting the societies of the CEE countries. In line with the findings presented by authors in this Special Issue, as well as more generally, it is possible to suggest certain future paths to the development of tourism in the CEE countries, as well as associated research tasks, as follows:

- the sustainable development of tourism;

- analysis of tourism heritage, historical memory, local identity and symbols in the creation of the "tourismscape" (on local, regional, national, transboundary and European scales);

- analysis of tourism's impact on everyday life in local communities;

- changes in border and visa regimes - cross-border development of areas on Schengen borders; facilitation at the EU's external frontiers;

- the use of European Union funding (directly or indirectly) in developing tourism; the efficiency of the EU programmes operating at different locations;

- accessibility of tourist areas on different scales and in respect of different actors;

- the use of new technologies in marketing, tourist information systems, etc.;

- analysis of strategic and planning documents, marketing and promotion in the development of tourism;

- tourist-destination management and the development of relevant governance;

- analysis, creation and participation in tourism planning, urban development, tourism policy, resource management and economic and social development through tourism (also as a part of applied geography);

- the development of new methods in tourism studies.
Obviously, this list does not represent all possible topics or paths where future research into tourism is concerned. Furthermore, there is seen to be a plurality of theoretical and methodological choices available to such geographical research. Indeed, as Timothy (2018) stressed: "geographers are certainly not limited to the methods they use nor the types of tourism they concentrate on. We are known for qualitative and quantitative analysis and utilizing a wide range of data-collection methods. As well, geographers are used to addressing a variety of concepts and research questions related to many types of tourism". A prominent area of increasing importance is the crossover between tourism and geospatial technology. Much scholarly attention is currently devoted to 'neogeography' or 'volunteered geographic information (VGI)', in what is commonly known as the user-generated content (Timothy 2018). Many new topics have appeared and could serve as the core of the next research agenda. Nevertheless, space, place and location remain at the heart of geography, empowering geographers to evaluate tourism holistically and on multiple scales (see Saarinen 2017, Timothy 2018).

The present Special Issue seeks to push forward the geographical study of tourism in the contexts of the CEE countries, where tourism has not necessarily received sufficient attention. It is therefore our great hope that tourism can play an important role in geographical research in the CEE countries in future. Tourism geography has made many key contributions to the field of tourism studies, and has played its major role in guiding contemporary discussions and relevant research agendas (Saarinen 2019). Against that backdrop, we hope that this Special Issue will offer further ways, ideas and information on how to approach tourism and tourist destinations as geographically and theoretically rich ideas present in the regional and local development contexts in the CEE countries. 


\section{References}

Banaszkiewicz M., Graburn N., Owsianowska S., 2017. Tourism in (post)socialist Eastern Europe. Journal of Tourism and Cultural Change, vol. 15, no. 2, pp. 109-121. https://doi.org/10.1080/14766825.2016.1260089

Bănică A., Camară G., 2011. Accessibility and tourist function development of the Romanian small towns. GeoJournal of Tourism and Geosites, vol. 7, no. 1, pp. 22-133.

Dołzbłasz S., 2018. A network approach to trans- border cooperation studies as exemplified by poland's eastern border. Geographia Polonica, vol. 91, no. 1, pp. 63-76. https://doi.org/10.7163/GPol.0091

Erikson R., Goldthrope J.H., 1992. The constant flux: A study of class mobility in industrial societies. Oxford: Clarendon Press.

Grimwade N., 1989. International trade: new patterns of trade, production and investment. London: Routledge.

Hall C.M., 2003. Introduction to tourism: Dimensions and issues. 4th edition, Melbourne: Pearson Education.

Hall D., 2000. Cross-border movement and the dynamics of transition processes in Southeastern Europe. GeoJournal, vol. 50, pp. 249-253. https://doi.org/10.1023/A:1007153615095

Kolosov V., Więckowski M., 2018. Border changes in Central and Eastern Europe. Geographia Polonica, vol. 91, no. 1, pp. 5-16. https://doi.org/10.7163/GPol.0106

Mayer M., Zbaraszewski W., Pieńkowski D., Gach G., Gernert J., 2019. Barrier effects of the PolishGerman border on tourism and recreation: The case of protected areas. An introduction [in:] CrossBorder Tourism in Protected Areas. Geographies of Tourism and Global Change, Cham: Springer, pp. 1-17. https://doi.org/10.1007/978-3-030-05961-3_1

Michniak D., Więckowski M., Stępniak M., Rosik P., 2015. The impact of selected planned motorways and expressways on the potential accessibility of the Polish-Slovak borderland with respect to tourism development. Moravian Geographical Report, vol. 23, no. 1, pp. 13-20.

https://doi.org/10.1515/mgr-2015-0002

Müller D., 2018. Tourism and transition [in:] Müller D., Więckowski M. (eds.), Tourism in transitions: Recovering decline, managing change, Cham: Springer, pp. 1-20. https://doi.org/10.1007/978-3-319-64325-0_1

Nilsson J.K., 2018. Mobility and regionalisation: Changing patterns of air traffic in the Baltic Sea region in connection with European integration. Geographia Polonica, vol. 91, no. 1, pp. 77-93. https://doi.org/10.7163/GPol.0092

Poon A., 1993. Tourism, technology and competitive strategies. Wallingford: CAB International.

Riley R., 2000. Embeddedness and the tourism industry in the Polish southern uplands: Social Processes as an Explanatory Framework. European Urban and Regional Studies, vol. 7, no. 3, pp. 195-210. https://doi.org/10.1177/096977640000700301

Sykora L., Bouzanovski S., 2012. Multiple transformations: Conceptualising the post-communist urban transition. Urban Studies, vol. 49. no. 1. pp. 43-60, https://doi.org/10.1177/0042098010397402

Saarinen J., 2004. 'Destinations in change': The transformation process of tourist destinations. Tourist Studies, vol. 4, no. 2, pp. 161-179. https://doi.org/10.1177/1468797604054381

Saarinen J., 2014. Transforming destinations: A discoursive approach to tourist destinations and development [in:] A. Viken, B. Granås (eds.), Tourism destination development: Turns and tactics, pp. 47-62. London: Routledge. https://doi.org/10.4324/9781315550756

Saarinen J., 2017. Enclavic tourism spaces: Territorialization and bordering in tourism destination development and planning. Tourism Geographies, vol. 19, no. 3, pp. 425-437.

https://doi.org/10.1080/14616688.2016.1258433 
Saarinen J., 2019. Not a serious subject?! Academic relevancy and critical tourism geographies [in:] D.K. Muller (ed.), Tourism geographies: A research agenda, Cheltenham: Edgar Elgar, pp. 33-41. https://doi.org/10.4337/9781786439314.00011

Saarinen J., Kask T., 2008. Transforming tourism spaces in changing socio-political contexts: The case of Pärnu, Estonia, as a tourist destination. Tourism Geographies, vol. 10, no. 4, pp. 452-473. https://doi.org/10.1080/14616680802434072

Studzieniecki T., Meyer B., 2017. The programming of tourism development in Polish cross-border areas during the 2007-2013 period. 6th Central European Conference in Regional Science - CERS, pp. 506-516.

Stryjakiewicz T., 1998. The changing role of border zones in the transforming economies of East-Central Europe: The case of Poland. GeoJournal, vol. 44, no. 3, pp. 203-213. https://doi.org/10.1023/A:1006866122198

Timothy D.J., Saarinen J., 2013. Cross-border cooperation and tourism in Europe [in:] C. Costa, D. Buhalis, E. Panyik (eds.), Trends in European Tourism Planning and Organisation, Bristol: Channel View, pp. 64-74.

Timothy D.J., Saarinen J., Viken A., 2016. Editorial: Tourism issues and international borders in the Nordic Region. Scandinavian Journal of Hospitality and Tourism, vol. 16, iss. sup. 1, pp. 1-13. https://doi.org/10.1080/15022250.2016.1244504.

Timothy D.J., 2018, Geography: The substance of tourism. Tourism Geographies, vol. 20, no. 1, pp. 166-169. https://doi.org/10.1080/14616688.2017.1402948

Tóth G., Dávid L., 2010. Tourism and accessibility: An integrated approach. Applied Geography, vol. 30, no. 4, pp. 666-677. https://doi.org/10.1016/j.apgeog.2010.01.008

Więckowski M., 2008. New international mobility of Poles. Espace, Populations, Societes, 2 , pp. 261-270. https://doi.org/10.4000/eps.2509

Więckowski M., 2010. Tourism development in the borderland of Poland. Geographia Polonica, vol. 83, no. 2, pp. 67-81. https://doi.org/10.7163/gpol.2010.2.5

Williams A.M., Baláž V., 2002a. International petty trading: Challenging practices in trans-Carpathian Ukraine. International journal of Urban and Regional Research, vol. 26, no. 2, pp. 323-342. https://doi.org/10.1111/1468-2427.00382

Williams A.M., Baláž V., 2002b, The Czech and Slovak republics: Conceptual issues in the economic analysis of tourism in transition. Tourism Management, vol. 23, no. 1, pp. 37-45.

https://doi.org/10.1016/s0261-5177(01)00061-9

(C) Marek Więckowski • Jarkko Saarinen

(C) Geographia Polonica

(C) Institute of Geography and Spatial Organization

Polish Academy of Sciences • Warsaw • 2019
Article first received • September 2019

Article accepted • November 2019

Open acces article under the CC BY 4.0 license 
